Nat. Hazards Earth Syst. Sci., 17, 2289-2300, 2017

https://doi.org/10.5194/nhess-17-2289-2017

(C) Author(s) 2017. This work is distributed under

the Creative Commons Attribution 3.0 License.

\title{
Intense precipitation events in the Central Range of the Iberian Peninsula
}

\author{
Manuel Mora García ${ }^{1}$, Jesús Riesco Martín ${ }^{2}$, José Miguel Sánchez Llorente ${ }^{3}$, Luis Rivas Soriano ${ }^{3}$, and \\ Fernando de Pablo Dávila ${ }^{3}$ \\ ${ }^{1}$ Spanish Meteorological Agency (AEMET), Oviedo, Spain \\ ${ }^{2}$ Spanish Meteorological Agency (AEMET), Malaga, Spain \\ ${ }^{3}$ Department of Fundamental Physics, University of Salamanca, Salamanca, Spain
}

Correspondence: Fernando de Pablo Dávila (fpd123@usal.es)

Received: 15 February 2017 - Discussion started: 1 March 2017

Revised: 23 October 2017 - Accepted: 25 October 2017 - Published: 13 December 2017

\begin{abstract}
Intense orographic precipitation associated with the Central Range was analysed using data of maximum accumulated precipitation in $24 \mathrm{~h}$, occurring between 1958 and 2010. The 18 selected episodes were associated with a southwesterly tropospheric flow, a low-level jet, and high moisture flux at low levels. The observed moisture flux was higher than $100\left(\mathrm{~m} \mathrm{~g}(\mathrm{~s} \mathrm{~kg})^{-1}\right)$ and the dry and wet Froude numbers were greater than 1 . The selected area to study this synoptic situation was Gredos, broad and high range, which is located in the eastern part of the Central Range and generates a leeward "orographic shadow". The effect of the Central Range on the spatial distribution of precipitation on the Iberian Peninsula plateau results in a sharp increase in precipitation in the south of the Central Range, followed by a decrease to the north of this range.
\end{abstract}

\section{Introduction}

The factors affecting the development of precipitation are complex and the forecasting of precipitation is therefore difficult, particularly with the use of larger spatial and temporal resolutions (Llasat and Siccardi, 2010). Heavy precipitation is generally associated with a high moisture content, vertical movement, and static instability (Reale and Lionello, 2013; Chen et al., 2013). There are many studies addressing cases of heavy precipitation. Thus, for example, Schwartz et al. (1990) analysed the evolution of the convective environment during episodes of heavy precipitation, and FernándezMontes et al. (2014) and Garavaglia et al. (2014) studied the synoptic patterns typically associated with heavy precipitation.

Some authors have attempted to elucidate the key factors involved in the production of heavy precipitation or intense orographic precipitation. These factors include precipitable water (Bližňák et al., 2014), static instability (Funk, 1991), moisture at low levels (Massari et al., 2014), waves upstream from the area of heavy precipitation (Yu et al., 2015), and dynamically forced vertical movements associated with wind maxima in the high troposphere (Ma and Bosart, 1990). Other articles have analysed moisture flux convergence at low levels (Banacos and Schultz, 2005), orographic lifting of conditionally unstable air masses (Lin et al., 2001), and the fact that the maximum precipitation rate mainly depends on the ratio of mountain height to the level of free convection, the ridge/aspect ratio, and a parameter that measures the ratio of advective to convective timescales (Miglietta and Rotunno, 2009). Mountains can allow airflow or partially or completely block the flow. The Froude number $(F)$ or the wet Froude number $\left(F_{\mathrm{w}}\right)$ are used to characterize flow over mountains (e.g. Durram and Klemp, 1982; Colle, 2004; Chu and Lin, 2000; Chen and Lin, 2005). A value of Froude number lower than 1 (around 1) is associated with blocked (partially blocked) flow, while a value greater than 1 implies flow that passes over mountains.

Research efforts have also focused on the study of heavy precipitation episodes in different areas. For example, Chiao et al. (2004) and Foresti and Pozdnoukhov (2012) discussed heavy orographic precipitation in the Alps; Lang and Barros (2004) studied winter storms in the central Himalayas, 
(a)

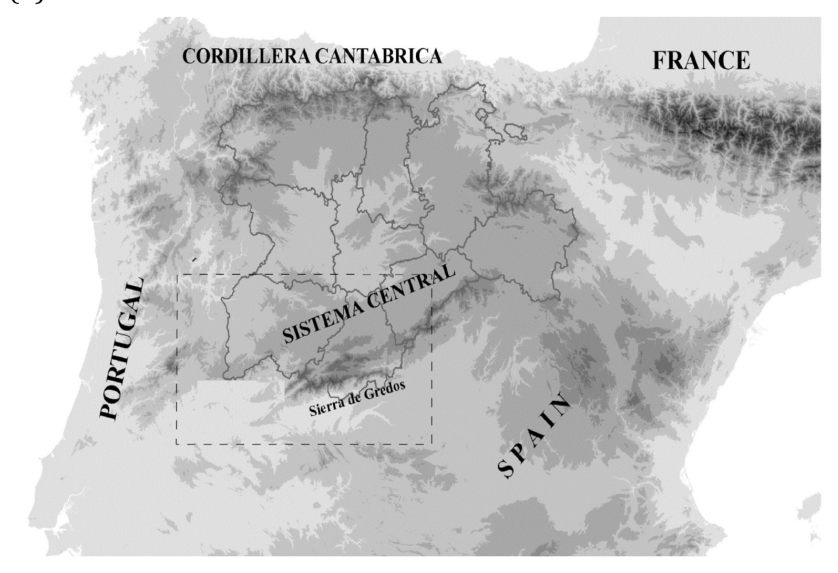

(b)

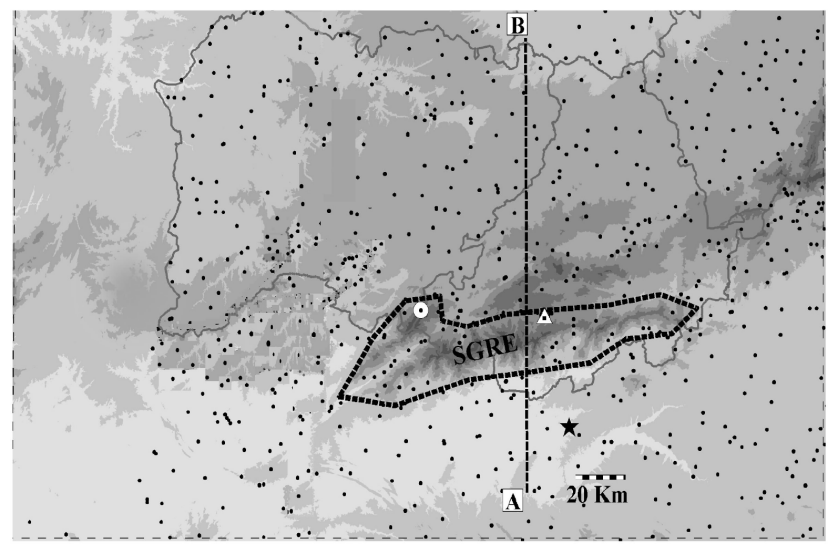

Figure 1. (a) Main orographic features in the northwestern Iberian Peninsula. Polygons represent the provinces of the region of Castilla-León. The dashed line corresponds to the area studied. (b) Study area: the polygon indicates the Gredos Range (SGRED); vertical line $\mathrm{AB}$ is the reference line for the orographic and precipitation profile shown in Fig. 2; black dots indicate the weather stations where precipitation was measured; the circle and triangle mark the automatic weather stations at La Covatilla and Navarredonda respectively; the star is the reference point for calculating the parameters used in the study $\left(40^{\circ} 16^{\prime} 31^{\prime \prime} \mathrm{N}, 5^{\circ} 09^{\prime} 32^{\prime \prime} \mathrm{W}\right)$.

and Prat and Barros (2010) studied the spatial gradients and vertical structure of orographic precipitation in the southern Appalachians. Yu and Cheng (2008) analysed heavy orographic precipitation associated with typhoon Xangsane. Further such examples can be found in the works of Grumm et al. (2002) and Schumacher and Johnson (2006) studying the USA, Chen et al. (2007) studying Taiwan, Teixeira and Prakki (2007) studying Brazil, Federico et al. (2008) and Buzzi et al. (2014) studying Italy, Stefanescu et al. (2014) for Romania, and Dasari and Salgado (2015) for Madeira Island (Portugal).

In the case of Spain, heavy precipitation episodes are characteristic of the weather, especially on and around the
Mediterranean coast and during late summer and autumn (Riesco et al., 2013). Jansa et al. (2001) reported that approximately $90 \%$ of heavy precipitation episodes in the internal basins of Catalonia between 1996 and 2002 were associated with warm and moist flows at low levels generated by extratropical cyclones. Rigo and Llasat (2004) show that during the period 1996-2000, 43 heavy rainfall events were detected in Catalonia (northeastern Spain) and the most of these events caused floods and serious damage. Ramis et al. (2009) studied heavy precipitation in the western Mediterranean and found that deep convection was the main cause. Several studies have classified the meteorological patterns associated with heavy precipitation. Thus, Romero et al. (1999) found the average geopotential field at the 925 and $500 \mathrm{hPa}$ pressure levels to be associated with heavy precipitation, and Martin-Vide (2002) classified the days with precipitation higher than $200 \mathrm{~mm}$ on the Spanish Mediterranean coast. Riesco et al. (2013) reported that severe precipitation episodes in the southern Iberian Peninsula may be classified into three types according to moisture flux at the $850 \mathrm{hPa}$ pressure level and the lifted index. All of these studies have analysed precipitation occurring in the same area, and hence we believe it is necessary to explore other areas of the Iberian Peninsula where heavy precipitation also falls. Fernandez-Montes et al. (2014) reported that a great amount of precipitation in the Iberian Peninsula can be concentrated in relatively few days, primarily conditioned by the atmospheric circulation and the moisture content, and they investigated the relationship between synoptic circulation type (CT) and the frequency of precipitation extremes ( $>90$ th percentile) in spring and autumn at 44 different stations. Merino et al. (2016) conducted an analysis of precipitation extreme events (PEEs) in Spain between 1960 and 2011. Thresholds for determining event severity were defined using 99th percentiles - regions of extreme weather risk were identified and then trends of extreme precipitation index were analysed using the Mann-Kendall test. Álvarez et al. (2017) analyse the competence of Spanish historical precipitation network and explore the physiographic influence of elevation and orientation at a national scale. Nearly 12000 monthly precipitation series recorded from the 19th century until the hydrological year 2004/05 are used, and comparable statistics and precipitation lapse rates are established once a completion of gaps is accomplished. González and Bech (2017) present a regional and seasonal study of extreme point rainfall scaling from $10 \mathrm{~min}$ to 2 years. The highest point-based rainfall list based on these temporal periods was calculated from the Spanish Meteorological Service (AEMET) precipitation database with more than 11000 rain gauge stations, with the longest series ranging from 1805 to 2014. Results indicate that daily precipitation extremes are mostly concentrated over the Mediterranean coast, while over durations from 1 month to 2 years extremes are located in southern and northwest Spain. 
Table 1. Date and values of several meteorological indices for each case considered, at the point $40^{\circ} 16^{\prime} 31^{\prime \prime} \mathrm{N}, 5^{\circ} 09^{\prime} 32^{\prime \prime} \mathrm{W}$. $V \cdot q$ is meridional moisture flux $\left(\mathrm{mg}(\mathrm{s} \mathrm{kg})^{-1}\right), P$ is number of $6 \mathrm{~h}$ intervals with $V \cdot q$ higher than the indicated value (70 or 100), $F$ is maximum dry Froude number, and $F_{\mathrm{W}}$ is maximum moist Froude number at the $850 \mathrm{hPa}$ pressure level. The instability indices CAPE ( $\mathrm{Jg}^{-1}$ ), TT (total totals), and $K$ (maximum CAPE) are also shown. Case 19 is not taken into account to calculate the average since it was a singular case with little precipitation.

\begin{tabular}{|c|c|c|c|c|c|c|c|c|c|c|}
\hline Case & Date & $\begin{array}{l}V \cdot q \text { maximum } \\
\quad\left(\mathrm{mg}\left(\mathrm{skg}^{-1}\right)\right.\end{array}$ & $\begin{array}{r}V \cdot q \text { mean } \\
\left(\mathrm{mg}(\mathrm{s} \mathrm{kg})^{-1}\right)\end{array}$ & $P>70$ & $P>100$ & $F$ & $F_{\mathrm{W}}$ & $\begin{array}{r}\mathrm{CAPE} \\
\left(\mathrm{Jkg}^{-1}\right)\end{array}$ & $\begin{array}{r}\mathrm{TT} \\
\left({ }^{\circ} \mathrm{C}\right)\end{array}$ & $\begin{array}{r}K \\
\left({ }^{\circ} \mathrm{C}\right)\end{array}$ \\
\hline 1 & 14-15 Nov 1963 & 162 & 120 & 6 & 3 & 1.4 & 1.5 & 801 & 52 & 35 \\
\hline 2 & 14-15 Jan 1975 & 114 & 100 & 8 & 5 & 1.4 & 1.5 & 287 & 51 & 30 \\
\hline 3 & 10 Jan 1970 & 102 & 102 & 1 & 1 & 1.1 & 1.1 & 619 & 52 & 29 \\
\hline 4 & 26-31 Dec 1981 & 171 & 103 & 8 & 3 & 1.5 & 1.6 & 534 & 53 & 34 \\
\hline 5 & 19-20 Oct 2004 & 195 & 135 & 8 & 6 & 1 & 1.1 & 1141 & 47 & 35 \\
\hline 6 & 6-7 Nov 1982 & 154 & 102 & 7 & 3 & 1.3 & 1.3 & 506 & 54 & 32 \\
\hline 7 & 7-8 Jan 1992 & 111 & 95 & 4 & 2 & 1 & 1 & 0 & 50 & 30 \\
\hline 8 & 16-18 Dec 1997 & 168 & 120 & 6 & 4 & 1.1 & 1.1 & 892 & 53 & 37 \\
\hline 9 & 23-25 Sep 1965 & 203 & 134 & 4 & 3 & 1.3 & 1.4 & 788 & 50 & 36 \\
\hline 10 & $22-25$ Oct 2006 & 206 & 127 & 15 & 11 & 1.3 & 1.4 & 1278 & 47 & 31 \\
\hline 11 & 8-16 Oct 1993 & 153 & 111 & 18 & 14 & 1.5 & 1.6 & 1517 & 52 & 28 \\
\hline 12 & 17-19 Dec 1958 & 160 & 124 & 5 & 4 & 1.1 & 1.2 & 816 & 50 & 35 \\
\hline 13 & 2-6 Feb 1972 & 129 & 87 & 12 & 5 & 1.4 & 1.4 & 600 & 52 & 31 \\
\hline 14 & 14-22 Nov 1989 & 147 & 112 & 12 & 7 & 1.4 & 1.5 & 640 & 50 & 31 \\
\hline 15 & 2-3 Dec 1987 & 116 & 101 & 4 & 3 & 1.1 & 1.1 & 140 & 52 & 31 \\
\hline 16 & 23-25 Nov 2006 & 193 & 144 & 5 & 5 & 1.8 & 1.9 & 261 & 44 & 32 \\
\hline 17 & 4-8 Dec 2010 & 110 & 91 & 6 & 2 & 0.8 & 0.8 & 821 & 54 & 31 \\
\hline 18 & 21-22 Dec 2010 & 87 & 85 & 2 & 0 & 0.7 & 0.8 & 497 & 51 & 32 \\
\hline 19 & 27-28 Feb 2010 & 114 & 103 & 3 & 1 & 1.1 & 1.2 & 441 & 45 & 28 \\
\hline Average & & 149 & 111 & 7 & 4 & 1.3 & 1.4 & 674 & 51 & 32 \\
\hline
\end{tabular}

The use of information obtained from statistical or case studies of precipitation episodes obtained from post-event investigation is needed to improve the forecasting of precipitation and is the basis of effective operative warning for flooding due to extreme heavy precipitation, such as that based on the European precipitation index (Alfieri and Thielen, 2015). In the present study we analysed episodes that featured more intense orographic precipitation and also had high instability index values during the years 1958 to 2010, which affected the Central Range of the Iberian Peninsula, but specifically those that occurred in the southern part of the area. This work is supplemented by including a study of meteorological indices that can help in the characterization of intense orographic precipitation. Finally, we analyse in detail two examples of episodes that demonstrate the direct application of the indices described above and that outline the difficulties involved in the study of orographic precipitation.

\section{Study area and data}

The study area is focused on the eastern part of the Central Range, comprising the Gredos Range (SGRED, Fig. 1). This mountain range separates valleys of the Duero Basin from those of the Tajo Basin and has a maximum altitude of $2592 \mathrm{~m}$ and an average elevation of $1200 \mathrm{ma}$.s.l.
A highly irregular relief characterizes this zone and the barrier is not uniform in height, width, or orientation, such that from the point of view of index calculation many simplifications must be made. The eastern part of the Central Range comprises the Gredos Range, which forms the massif of the Central Range and is very wide. In addition, most of the Gredos Range, where the south slopes are much more abrupt than the leeward side, separates the southern plateau, with a lower altitude (about 400 ma.s.1.), from the northern plateau (800 ma.s.1.).

From the climatological data network, we selected the 18 episodes with the heaviest precipitation accumulated in $24 \mathrm{~h}$ ( $>100 \mathrm{~mm}$ in at least one observatory inside the study area) in the western part of the Central Range during the period 1958-2010 (Table 1). Episode 19 was included as a case study despite having a maximum precipitation daily slightly less than $100 \mathrm{~mm}$, because it shows by example the importance of the time duration of the rain episode. The data regarding precipitation were obtained from the climatological database of the Spanish Meteorological Service (Agencia Estatal de Meteorologia (AEMET)), which has worldclass observatories equipped with staff, automatic stations, and meteorological collaborators, subject to various quality controls. Table 2 shows the accumulated precipitation and the precipitation in $24 \mathrm{~h}$ corresponding to the observatory 
(a)

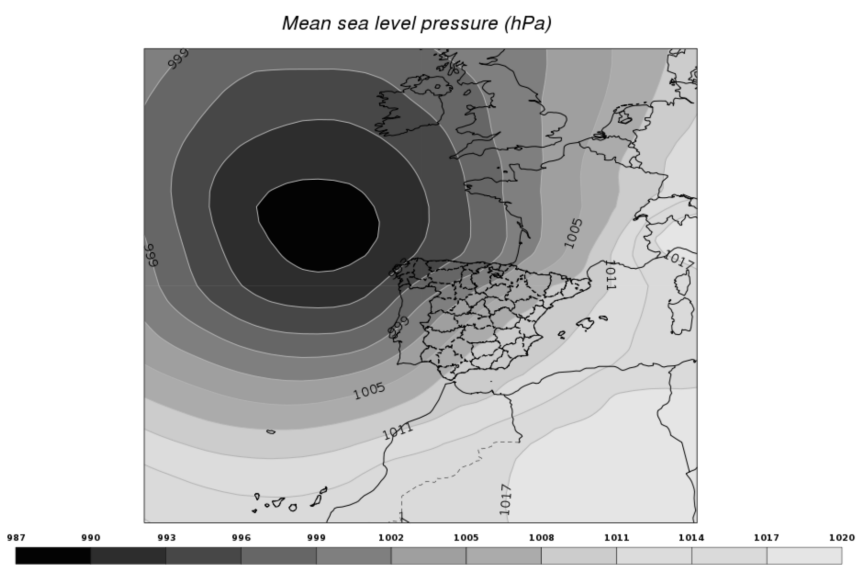

(b)

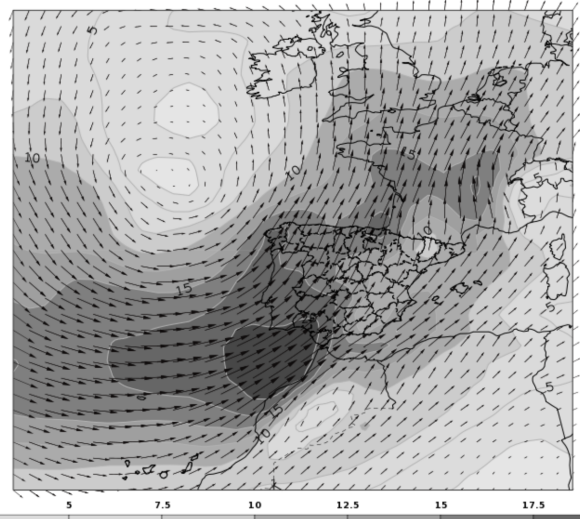

(c)

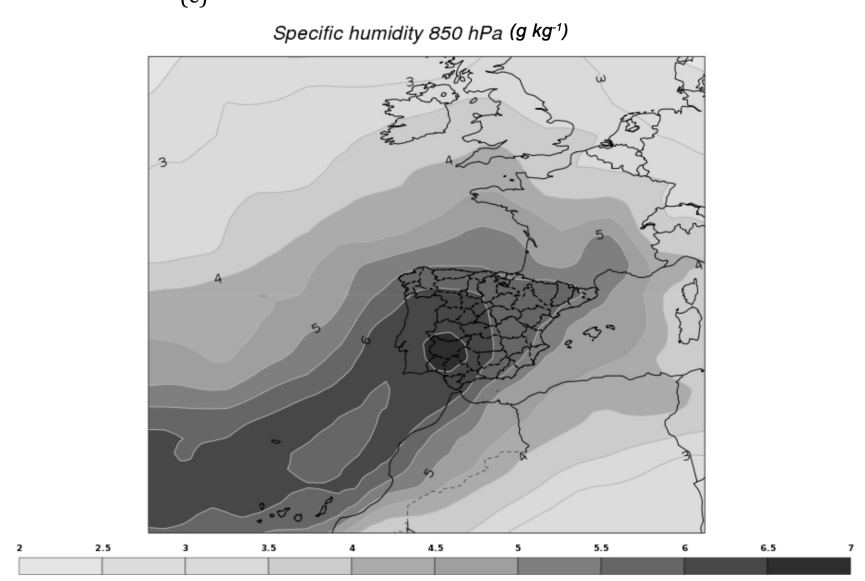

(d)

$\mathrm{Z} 500 \mathrm{hPa}(\mathrm{m})$

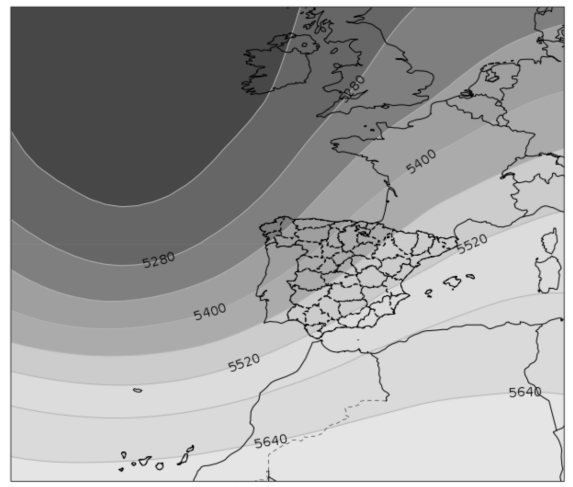

Figure 2. Average fields for the episodes studied (listed in Table 1) at 12:00 UTC of (a) mean sea level pressure (hPa); (b) wind (m s$\left.{ }^{-1}\right)$ and (c) specific humidity $\left(\mathrm{g} \mathrm{kg}^{-1}\right)$ at the $850 \mathrm{hPa}$ pressure level; (d) geopotential (m) at the $500 \mathrm{hPa}$ pressure level.

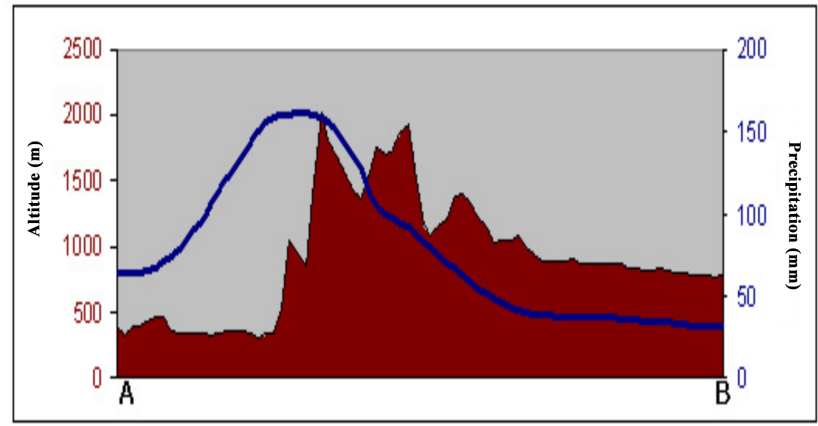

Figure 3. Average precipitation (all events) (line) and orographic (shaded) profiles along line AB (see Fig. 1b).

that reported the maximum value in the study area. Data for the other meteorological fields were obtained from the ERA-40 database of the European Centre for Medium Range Weather Forecasting (ECMWF) for the 1958-2002 period (Uppala et al., 2005) and directly from the ECMWF model for the 2003-2010 interval (http://apps.ecmwf.int/datasets/ data/era40-daily/levtype $=\mathrm{pl} /$ ).

The following parameters were calculated for each precipitation episode: mean and maximum precipitation; meridional moisture flux at the $850 \mathrm{hPa}$ pressure level (obtained by multiplying the $850 \mathrm{hPa}$ meridional component of wind velocity and the specific humidity, $V \cdot q$ ); the dry and moist Froude numbers (calculated as $F=V(N h)^{-1}$, with $V$ the meridional wind, $N$ the dry or moist Brunt-Väisälä frequency, and $h$ the obstacle height); convective available potential energy (CAPE); and the total totals (TT) and $K$ instability indices. We used the meridional wind component instead of the perpendicular component. The Central Range is clearly west-east oriented, so we believe that the wind meridional component is an appropriate estimate of the flow in the mountains and therefore our calculated values can be considered as estimates of the Froude number. In the present study, the above-mentioned parameters were calculated (kriging with $\operatorname{ArcGIS}^{\circledR}$ software) at $40^{\circ} 16^{\prime} 31^{\prime \prime} \mathrm{N}, 5^{\circ} 09^{\prime} 32^{\prime \prime} \mathrm{W}$ (belonging to the Gredos Range area, Fig. 1b), where southerly 
(a)

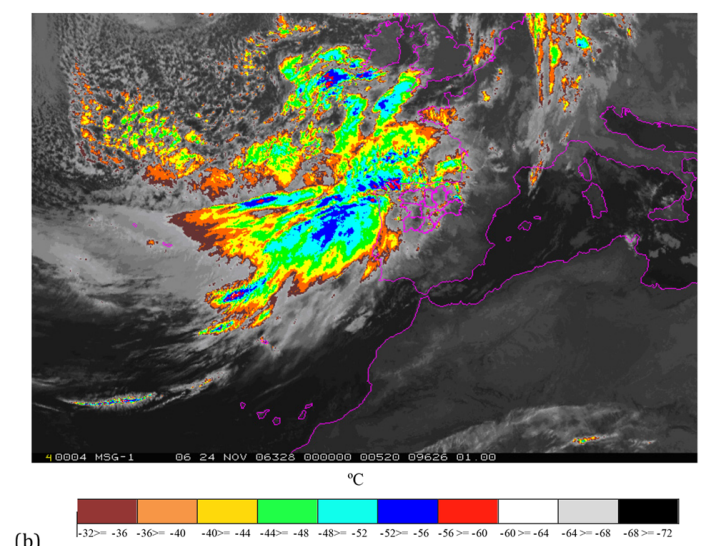

(b)

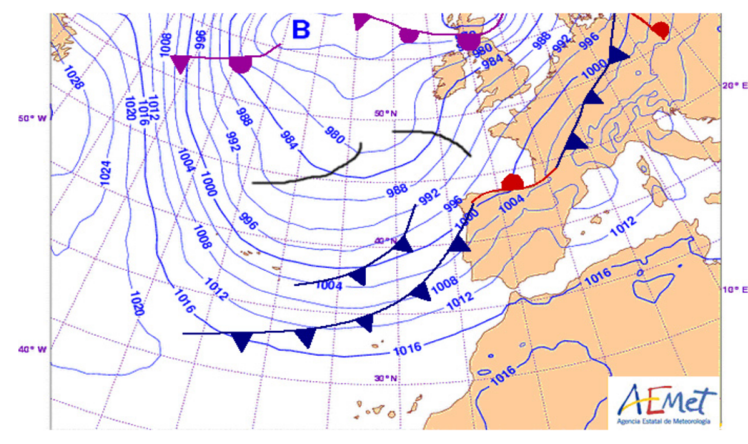

(c)

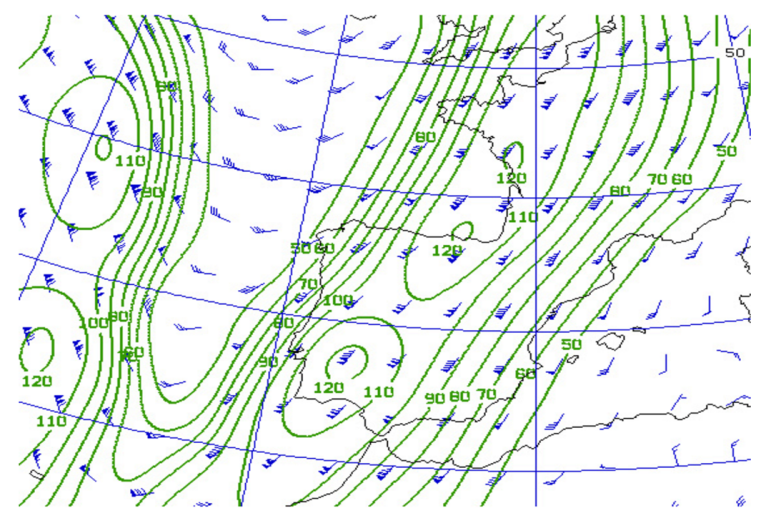

(d)

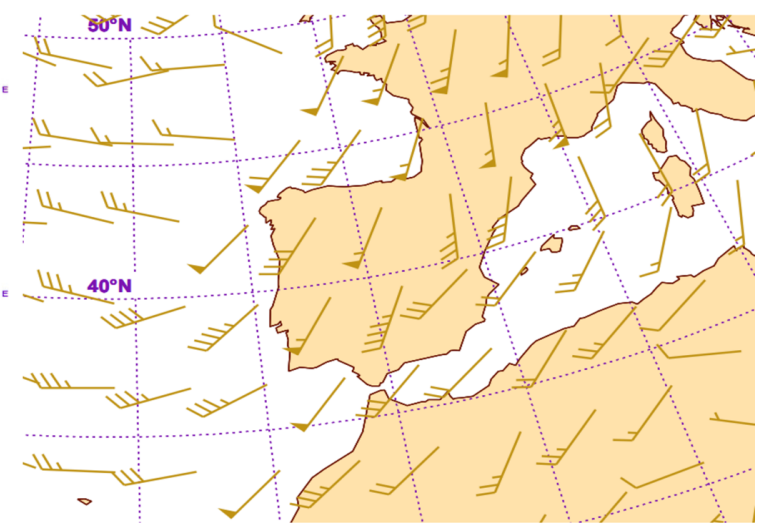

Figure 4. 23-25 November 2006: (a) infrared channel image from MSG on 24 November at 00:00 UTC; (b) surface pressure pattern on 24 November at 00:00 UTC; (c) $300 \mathrm{hPa}$ wind pattern (lines are isotachs, units labelled in knots) on 25 November at 12:00 UTC; and (d) $850 \mathrm{hPa}$ wind pattern (knots) over the Iberian Peninsula of 25 November at 00:00 UTC.

winds must surpass a height difference of $\sim 1500 \mathrm{~m}$, and the Central Range reaches its maximum altitude (2592 ma.s.1.) - and the maximum slope $(\Delta h / \Delta x)$ is $\sim 0.09$ with a mean value in the southern hills of 0.05 . It should be mentioned that precipitation is very difficult to interpolate in mountainous areas, so that we considered that the impact of the interpolation method on the area-averaged precipitation is small and used the kriging interpolation method because it is the default method which comes built-in in the ArcGIS ${ }^{\circledR}$ software.

\section{Results and discussion}

The values of the meteorological parameters considered in this study for each precipitation event are shown in Table 1 . Figure 2 shows the composite fields at 12:00 UTC of sea level pressure, wind, and specific humidity at the $850 \mathrm{hPa}$ pressure level and geopotential at the $500 \mathrm{hPa}$ pressure level. These maps were built using data from the 18 episodes of severe rainfall indicated in Table 1. The synoptic situation of each individual event is similar to that of the average. Figure 2a shows a low-pressure system at sea level located on the northwestern Iberian Peninsula with southwesterly winds over the Central Range (Fig. 2b). This is a moist flow, and thus increased the humidity over the study area, especially on the south slopes, as shown in Fig. 2c. The figure also shows a tongue of moist air at low levels over the southwestern Iberian Peninsula, which reached values greater than $6 \mathrm{~g} \mathrm{~kg}^{-1}$ over the study area. Moreover, a high wind speed was observed at the $850 \mathrm{hPa}$ pressure level (Fig. 2b), where a low-level jet stream, with a wind speed greater than $20 \mathrm{~m} \mathrm{~s}^{-1}$, was apparent. A north-south-oriented mid-level trough located to the west of the Iberian Peninsula (see Fig. 2d) and moderate values of the instability indices (Table 1) were other common characteristics associated with the heavy precipitation events studied in this work. The average values in the mean and maximum meridional moisture fluxes were 110 and $147 \mathrm{mg}(\mathrm{s} \mathrm{kg})^{-1}$ respectively, and in most cases the individual values were higher than 100. As mentioned, Lin et al. (2001) defined the $U(\Delta h / \Delta x) q$ index ( $U$ is the meridional component of wind velocity, $\Delta h / \Delta x$ is the mountain slope, and $q$ is the mixing ratio) and reported that heavy orographic precipitation in the Alps was associated with values higher than $4.7 \mathrm{~m} \mathrm{~s}^{-1}$ at low levels. When 
(a)

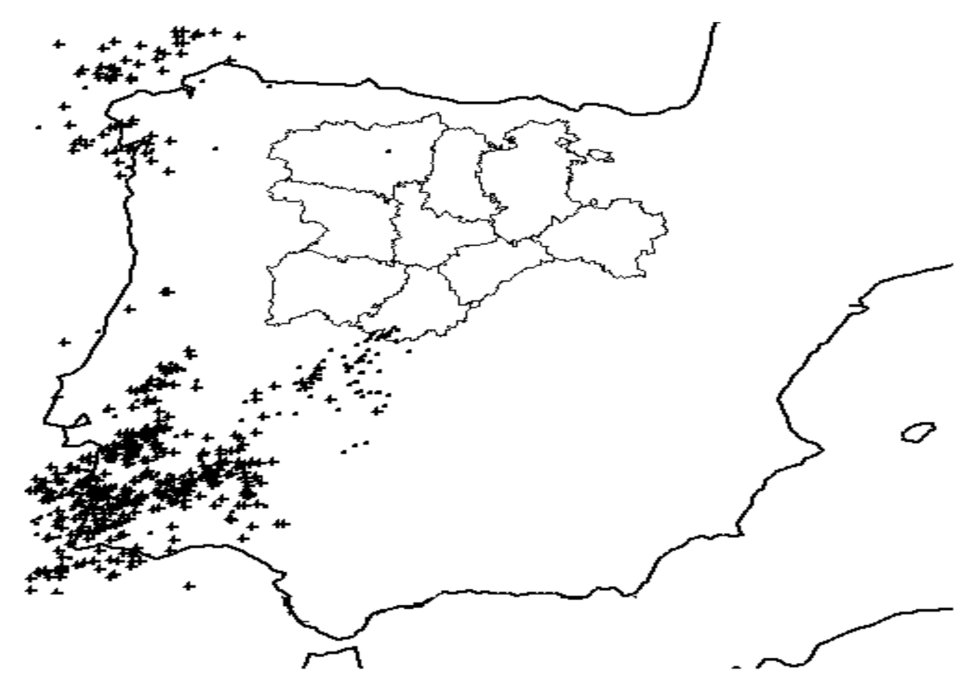

(b)

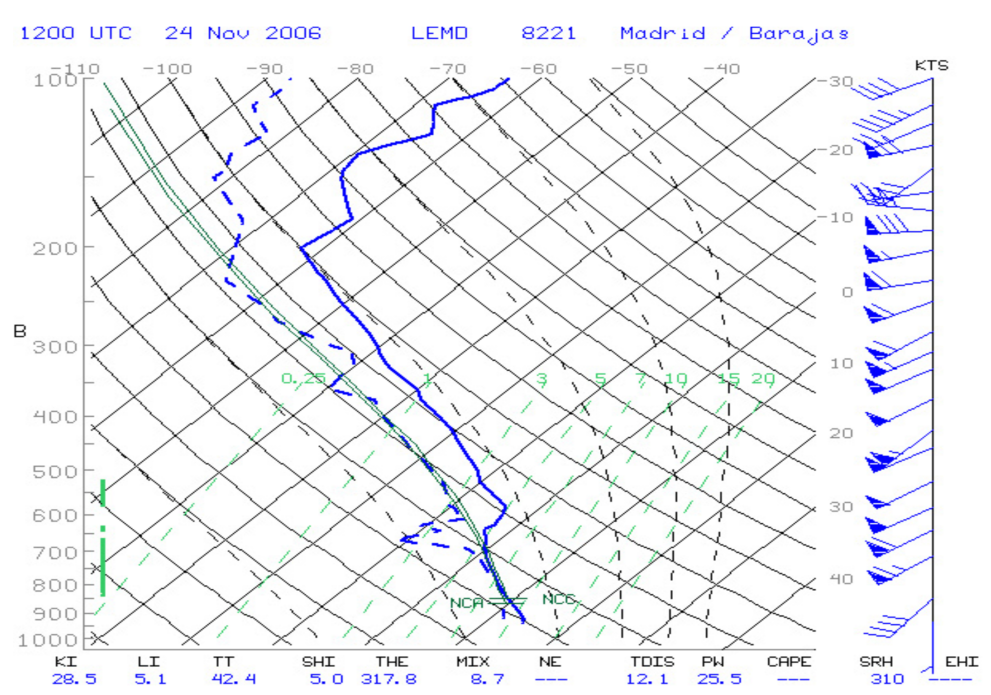

Figure 5. (a) Cloud-to-ground lightning flashes detected (+ positive flashes) on 24 November over the Iberian Peninsula, and (b) Madrid sounding $\left(40^{\circ} 27^{\prime} \mathrm{N}, 3^{\circ} 43 \mathrm{~W}\right)$ on 24 November at 12:00 UTC.

this index was calculated for the Central Range using the data in Table 1, the mean value was 5.5. $\mathrm{m} \mathrm{s}^{-1}$. Thus, this index also indicates the risk of heavy orographic precipitation for the Central Range. Regarding the dry and wet Froude numbers, these ranged between 0.7 and 1.9, the maximum averaged values being 1.2 and 1.3 respectively, corresponding to moderate values of this index. The shape of the mountain can be approached by using a slope of $1.6 \mathrm{~km} / 35 \mathrm{~km} \approx 0.05$ of the windward mountain barrier (which is the mean value in the southern hills). Chu and Lin (2000) and Chen and Lin (2005) established four types of flow regimes as a function of $F_{\mathrm{w}}$ and CAPE:

- Type I ( $F_{\mathrm{w}}$ small): a convective system of up-stream propagation.
- Type II ( $F_{\mathrm{w}}$ moderate): a long-lasting convective flow over the mountain.

- Type III $\left(F_{\mathrm{w}}\right.$ large): a convective system over the mountain that propagates similarly to the flow.

- Type IV ( $F_{\mathrm{w}}$ small and low CAPE): orographic stratiform system, which probably propagates downstream.

Therefore, in principle, the greatest windward precipitation would occur with moderate or small Froude number.

With the values obtained in this study, in nearly all cases a type III flow would be obtained, which implies the presence of a convective system propagating similarly to the flow. However, it should be taken into account that with low CAPE and moderate wind intensity, the flow would be type IV in- 
(a)

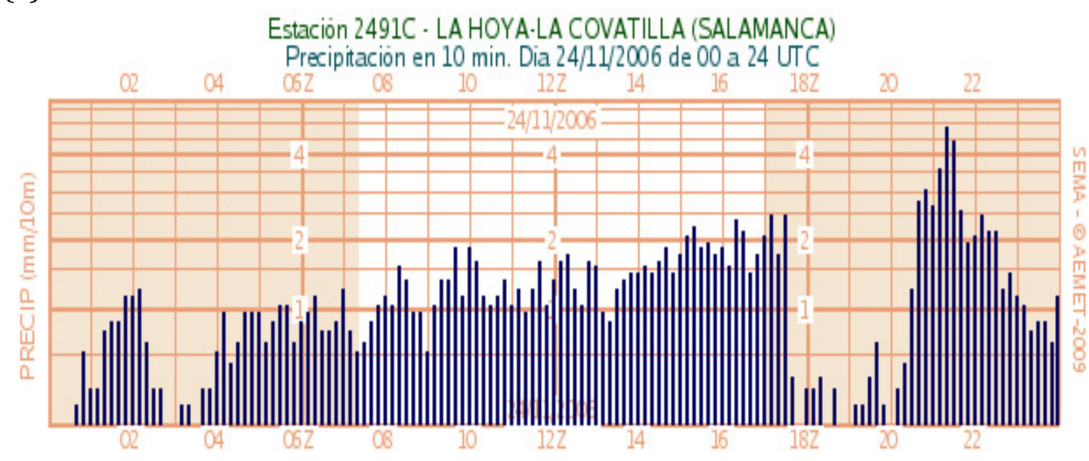

(b)

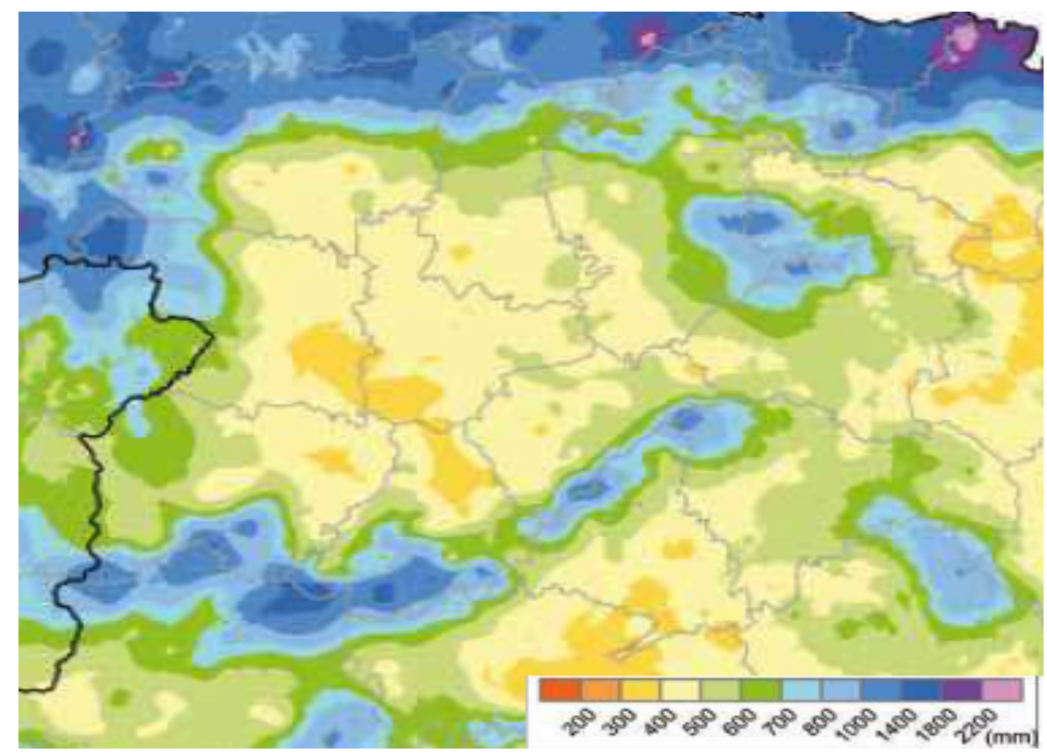

Figure 6. (a) Temporal distribution of precipitation observed at the La Covatilla weather station (see Fig. 1b) on 24 November; (b) spatial pattern of average precipitation observed over the area for the period 1971-2000 including to the north of Extremadura.

stead of type III (Chen and Lin, 2005), giving rise to stratiform precipitation. In any case, both convective and stratiform precipitation give large amounts of total precipitation (including possible flooding), if the flow persists for many hours.

Table 2 shows the precipitation data of the Gredos Range (SGRED) (Fig. 1b). González and Bech (2017) studied extreme rainfall in Spain. They found that extreme rainfall may be expressed as a potential law, and their reported law gives values around $270 \mathrm{~mm}$ in $24 \mathrm{~h}$ for inland Spain, and $260 \mathrm{~mm}$ in $24 \mathrm{~h}$ for the province of Avila. These numbers are in agreement with the values shown in Table 2, especially taking into account that González and Bech (2017) only considered extreme rainfall in their study. Colle (2004) reported that with moderate winds $\left(\sim 20 \mathrm{~m} \mathrm{~s}^{-1}\right)$ and a freezing level over $750 \mathrm{hPa}$, the drop in the freezing level increases as mountain barrier height and width increase. Moreover, mountain waves when the wind is strong, the static stability is low, and the mountain barrier is narrow, may favour intense vertical movement. The orographic and precipitation profile across the SGRED is depicted in Fig. 3. This profile was calculated following the line $A B$ indicated in Fig. 1b. Figure 3 shows that precipitation over the SGRED increases sharply windward and that maximum values are reached on the upper third of the windward slope. Precipitation decreases sharply on the leeward slope, indicating an "orographic shadow" associated with the SGRED. Maximum precipitation is now located around the summit.

\subsection{Case study: 23-25 November 2006}

During this time frame (episode no. 16), the precipitation observed at several stations along the Central Range was more than $300 \mathrm{~mm}$. Figure 4a shows the infrared channel image from the Meteosat satellite and Fig. 4b shows the surface pressure pattern for 24 November at 00:00 UTC. A lowpressure system was affecting the North Atlantic area, with a minimum sea level pressure of $\sim 970 \mathrm{hPa}$ located west of 
Table 2. Maximum $\left(P_{\max }\right)$, in $24 \mathrm{~h}\left(P_{24}\right)$ and mean $\left(P_{\text {mean }}\right)$ precipitation observed in the Gredos Range (SGRED) during each case considered. The $P_{\text {mean }}$ has been calculated by the kriging interpolation method implemented in the ArcGIS ${ }^{\circledR}$ software. Case 19 is not taken into account to calculate the average since it was a singular case with little precipitation.

\begin{tabular}{lrrr}
\hline Case & $\begin{array}{r}P_{\max } \\
\text { SGRED } \\
(\mathrm{mm})\end{array}$ & $\begin{array}{r}P_{24} \\
\text { SGRED } \\
(\mathrm{mm})\end{array}$ & $\begin{array}{r}P_{\text {mean }} \\
\text { SGRED } \\
(\mathrm{mm})\end{array}$ \\
\hline 1 & 310 & 236 & 88 \\
2 & 274 & 235 & 96 \\
3 & 305 & 226 & 77 \\
4 & 504 & 215 & 240 \\
5 & 235 & 212 & 98 \\
6 & 322 & 210 & 116 \\
7 & 291 & 210 & 58 \\
8 & 377 & 207 & 145 \\
9 & 214 & 204 & 74 \\
10 & 317 & 202 & 103 \\
11 & 867 & 195 & 271 \\
12 & 223 & 200 & 111 \\
13 & 406 & 190 & 188 \\
14 & 694 & 199 & 300 \\
15 & 242 & 190 & 95 \\
16 & 310 & 183 & 88 \\
17 & 364 & 117 & 136 \\
18 & 270 & 116 & 74 \\
19 & 92 & 89 & 33 \\
\hline Average & 367 & 188 & 133 \\
\hline & & &
\end{tabular}

Table 3. Time variation for several meteorological indices along 26, 27 and 28 February 2010. TT and $K$ are the total totals and $K$ instability indices; $V \cdot q\left(\mathrm{mg}(\mathrm{s} \mathrm{kg})^{-1}\right), F$, and $F_{\mathrm{W}}$ are the meridional moisture flux, Froude number, and moist Froude number at the $850 \mathrm{hPa}$ pressure level.

\begin{tabular}{lrrrrr}
\hline $\begin{array}{l}\text { Day/ } \\
\text { UTC hour }\end{array}$ & $\begin{array}{r}V \cdot q \\
\left(\mathrm{mg}(\mathrm{skg})^{-1}\right)\end{array}$ & $\begin{array}{r}\mathrm{TT} \\
\left({ }^{\circ} \mathrm{C}\right)\end{array}$ & $\begin{array}{r}K \\
\left({ }^{\circ} \mathrm{C}\right)\end{array}$ & $F$ & $F_{\mathrm{W}}$ \\
\hline $26 / 18: 00$ & 25 & 38 & 20 & 0.32 & 0.33 \\
$27 / 00: 00$ & 42 & 40 & 19 & 0.33 & 0.33 \\
$27 / 06: 00$ & 119 & 39 & 26 & 0.74 & 0.76 \\
$27 / 12: 00$ & 146 & 45 & 28 & 0.87 & 0.91 \\
$27 / 18: 00$ & 77 & 42 & 20 & 1.09 & 1.2 \\
$28 / 00: 00$ & 12 & 32 & 6 & 0.26 & 0.27 \\
\hline
\end{tabular}

Ireland. A southwesterly moist air flow and several frontal systems were affecting the western Iberian Peninsula, moving from west to east. Figure $4 \mathrm{c}$ shows a deep north-southoriented trough at the $300 \mathrm{hPa}$ pressure level located west of the Iberian Peninsula, with a southwesterly low-level jet of $60 \mathrm{~m} \mathrm{~s}^{-1}$ over the central Iberian Peninsula. Chen and Lin (2001) reported that the presence of a jet at low levels exacerbates the windward precipitation, in agreement with what (a)

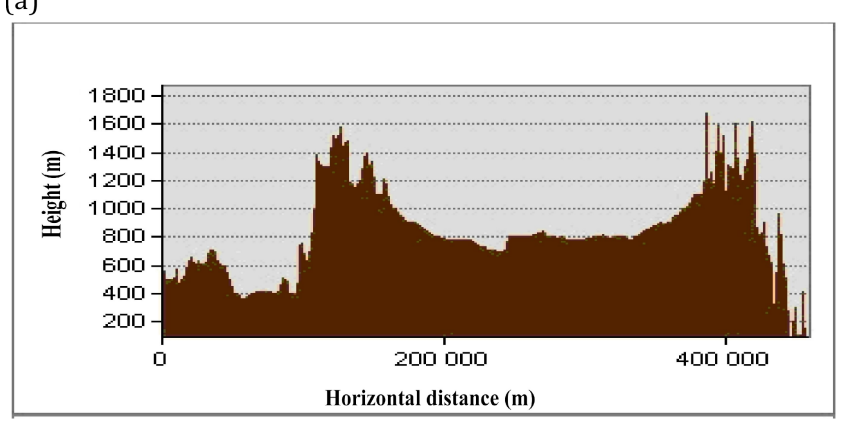

(b)

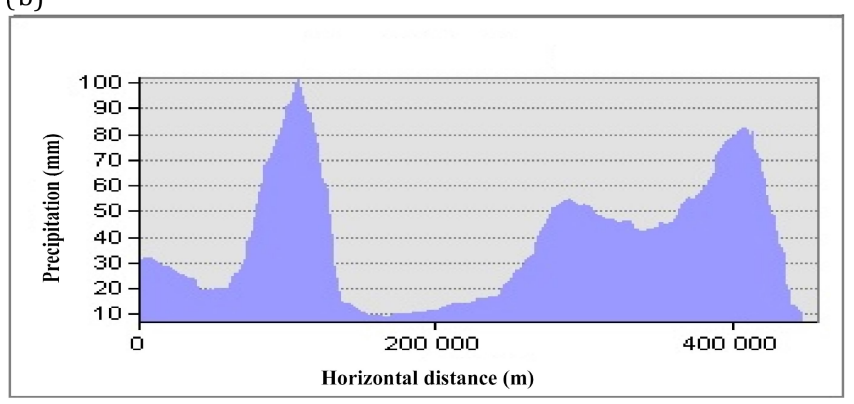

Figure 7. Topographic (a) and precipitation (b) profiles along a south-north-oriented line crossing the Gredos Range.

was observed in this case, where a southwesterly low-level jet stream of $30 \mathrm{~m} \mathrm{~s}^{-1}$ was also observed crossing the Central Range at the $850 \mathrm{hPa}$ pressure level on 25 November at 00:00 UTC (Fig. 4d) This meteorological situation generated a high moisture flux (see Table 1) and had a value of $7.2 \mathrm{~m} \mathrm{~s}^{-1}$ for the $U(\Delta h / \Delta x) q$ index, clearly higher than the threshold value reported by Lin et al. (2001) for the Alps $\left(4.7 \mathrm{~m} \mathrm{~s}^{-1}\right)$. The cloud-to-ground lightning flashes observed on 24 November are shown in Fig. 5a. The discharges were mainly located windward of the Central Range, indicating that flow was unstable. This is confirmed by the Madrid sounding $\left(40^{\circ} 27^{\prime} \mathrm{N}, 3^{\circ} 43^{\prime} \mathrm{W}\right)$ at 12:00 UTC (Fig. 5b) and the values of the instability indices (Table 1). The Froude number is large, both for dry and moist cases, indicating a type III flow regime. The automatic observation station located in the western Central Range and indicated by a circle in Fig. 1b recorded $157.7 \mathrm{~mm}$ from 00:00 to 24:00 UTC of 24 November and $16.8 \mathrm{~mm}$ for 25 November. The temporal distribution on 24 November is shown in Fig. 6a, and indicates that large amounts of precipitation occurred regularly during that day. The pattern of the spatial distribution of average precipitation (1971-2000) (Fig. 6b) shows the relevance of orographic precipitation in this area of the Iberian Peninsula.

Figure 7 shows the orographic profile and the precipitation along a south-north-oriented line crossing the SGRED. Precipitation decreased leeward of the broadest part of the Central Range, and returned in large amounts windward of the Cantabrian Range, located near the northern Spanish coastline (see Fig. 1a). This marked "orographic shadow" is con- 
(a)

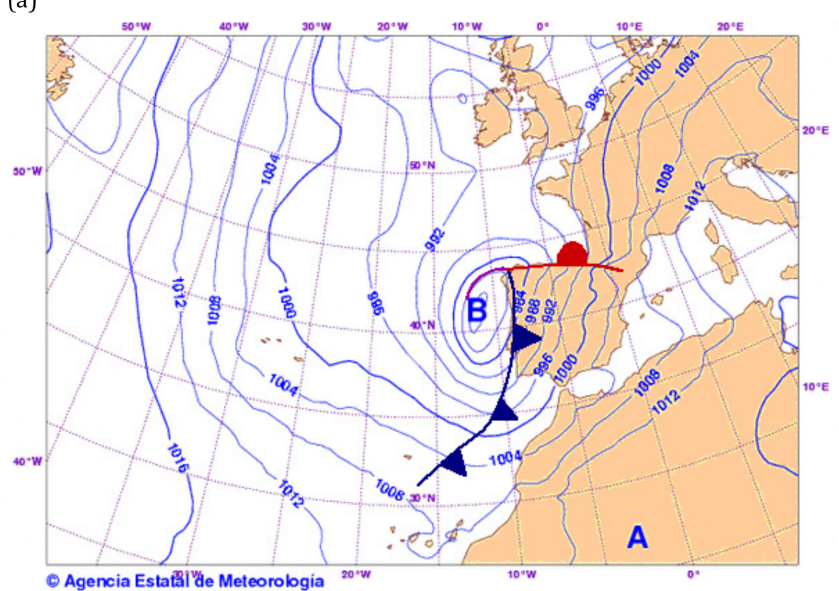

(b)

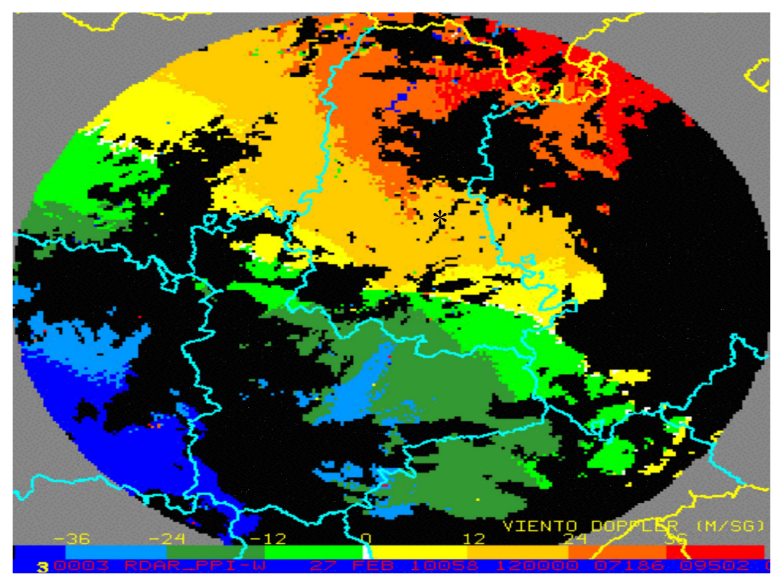

Figure 8. 27 February 2010: (a) Surface pressure pattern at 12:00 UTC; and (b) Doppler radar wind $\left(\mathrm{ms}^{-1}\right)$ plan position indicator (PPI) image over the Spanish region of Castilla-León. Negative values indicate approaching movement towards the radar position $(*)$. Positive values indicate that points are moving away from the radar position.

sistent with the shape (resembling a C) of the spatial pattern of precipitation shown in Fig. 6b. When the line was displaced to the west, the "orographic shadow" was not seen.

\subsection{Case study: 27-28 February 2010}

The time duration of the rain episode is an important factor. Large amounts of precipitation are not usually associated with episodes of short duration, and this was borne out by the case of episode no. 19. On 27 February 2010, the extratropical cyclone "Xinthya" crossed the northwestern part of the Iberian Peninsula. This was an event of explosive cyclogenesis, with hurricane-strength winds. It caused heavy rain and local floods in the west of Spain (Hickey, 2011). Figure 8a shows the surface-pressure pattern at 12:00 UTC. The fastmoving deep low of $976 \mathrm{hPa}$ was located close to the northern coastline of Portugal, resulting in strong southerly winds impinging on the Central Range. The same flow pattern was seen at medium and high levels (not shown). Doppler radar (Fig. 8b) shows a southwesterly low-level jet stream over the area studied.

Table 3 shows the sudden increase in the instability indices, Froude number, and meridional moisture flux during the morning and central hours of 27 February, together with the low values before and after the event. This was due to the short duration of the flow perpendicular to the mountain range (Fig. 9a). Therefore, the expected amount of rain cannot have been large. This is confirmed by the data shown in Fig. 9b, which shows the precipitation pattern. There is a broad area where precipitation measured between 30 and $40 \mathrm{~mm}$ and the maximum values were around $60 \mathrm{~mm}$.

\section{Summary and conclusions}

We have analysed episodes that featured intense orographic precipitation and also had high values in the instability indices that affected the Central Range of the Iberian Peninsula during the years 1958 to 2010 . The synoptic characteristics associated with the cases analysed were a strong southwesterly tropospheric flow, with jet streams at low and high levels, and high moisture contents at low levels. This flow was the result of low-pressure systems over the North Atlantic area, with associated fronts affecting the area studied. In general, the CAPE values and the TT and $K$ instability indices indicate static instability, in agreement with the lightning flashes observed, especially windward.

The moisture flux associated with the cases of heavy orographic precipitation considered here was $>100 \mathrm{mg}(\mathrm{s} \mathrm{kg})^{-1}$, and both the dry and moist Froude numbers were $>1$ on average (1.3), although in two events the value was 0.8 . These numbers can be considered to be characteristic for heavy precipitation in the Central Range when they are associated with long-lasting intervals. The broadest and highest part of this mountain range (Gredos Range) generates an "orographic shadow" leeward. Precipitation from frontal systems is increased sharply by orographic vertical movement in the Central Range, where updrafts associated with the warm conveyor belt are increased. The precipitation pattern in these cases resembles a "C", with heavy precipitation south of the mountain range. In several cases, the total amount of precipitation was moderate. This seems to have been caused by the short time interval during which airflow perpendicular to the orographic barrier persisted.

Data availability. The climatological data are the property of the AEMET (https://sede.aemet.gob.es/) and are not accessible to the public, although they can be obtained by request and upon payment. Data from the European Centre for Medium-Range Weather Forecasts (ECMWF) can be obtained free of charge at the URL mentioned on page 4 . 
(a)
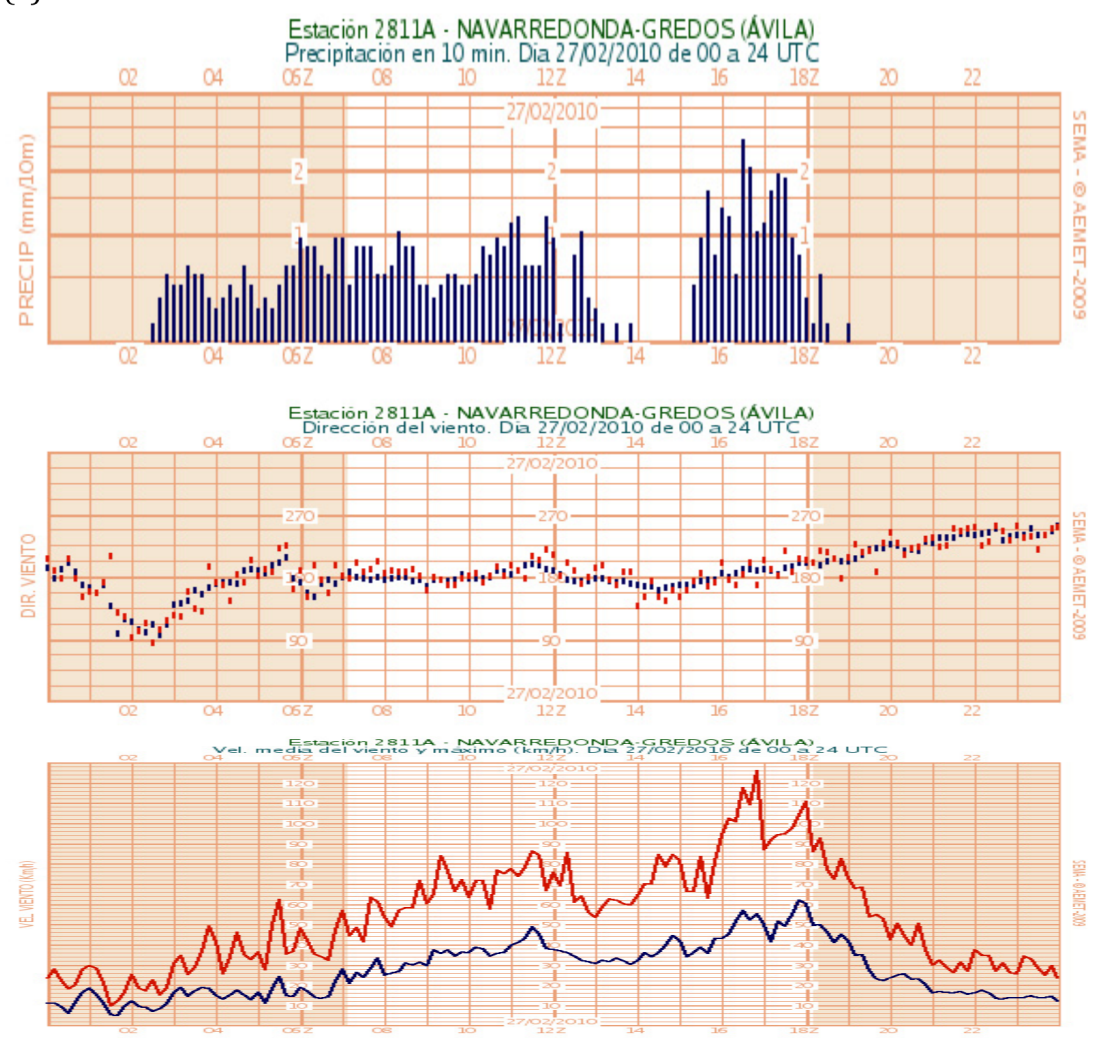

(b)

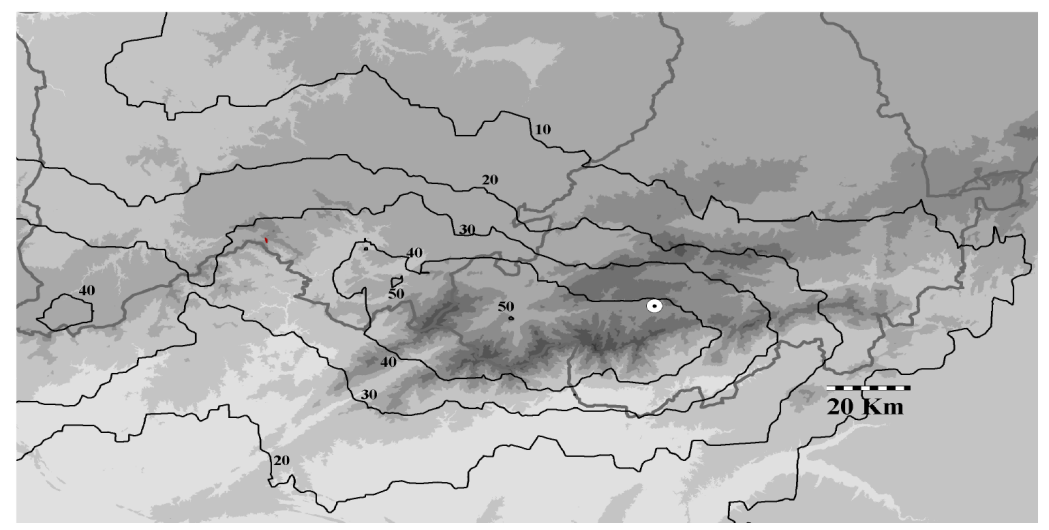

Figure 9. (a) Temporal distribution of precipitation, wind direction, and wind intensity (maximum and mean) on 27 February observed at the weather station at Navarredonda (see Fig. 1b); (b) spatial pattern of precipitation (isolines in mm) observed on 27 February over the study area (circle, Navarredonda automatic weather station).

Author contributions. MMG and FdPD designed the ideas and concepts of the work and prepared the paper. JRM and LRS carried out the analysis of the data and evaluated the results. JMSL prepared the graphics and checked the language. All the authors conducted a final review of the paper.

Competing interests. The authors declare that they have no conflict of interest.
Acknowledgements. The authors are grateful to AEMET (Agencia Estatal de Meteorología) for providing the data and partial support for this research. Special thanks are due to Carlos Jiménez Alonso.

Edited by: Thomas Glade

Reviewed by: three anonymous referees 


\section{References}

Alfieri, L. and Thielen, J.: A European precipitation index for extreme rain-storm and flash flood early warning, Meteorol. Appl., 22, 3-13, https://doi.org/10.1002/met.1328, 2015.

Alvarez-Rodriguez, J., Llasat, M. C., and Estrela, T.: Analysis of geographic and orographic influence in Spanish monthly precipitation, Int. J. Climatol., 37, 350-362, https://doi.org/10.1002/joc.5007, 2017.

Banacos, P. C. and Schultz, D. M.: The use of moisture flux convergence in forecasting convective initiation: historical and operational perspectives, Weather Forecast., 20, 351-366, 2005.

Bližňák, V., Sokol, Z., and Pešice, P.: The application of rapid scan data to the convective rainfall rate algorithm from SAF NWC for the area of the Czech Republic, Atmos. Res., 144, 82-94, 2014.

Buzzi, A., Davolio, S., Malguzzi, P., Drofa, O., and Mastrangelo, D.: Heavy rainfall episodes over Liguria in autumn 2011: numerical forecasting experiments, Nat. Hazards Earth Syst. Sci., 14, 1325-1340, https://doi.org/10.5194/nhess-14-1325-2014, 2014.

Chen, C., Chen, Y., Liu, C., Lin, P., and Chen, W.: Statistics of heavy precipitation occurrences in Taiwan, Weather Forecast., 22, 9811002, 2007.

Chen, C- S., Lin, Y.-L., Zeng, H.-T., Chen, C.-Y., and Liu, C.-L.: Orographic effects on heavy rainfall events over northeastern Taiwan during the northeasterly monsoon season, Atmos. Res., 122, 310-335, 2013.

Chen, S.-H. and Lin, Y. L.: Regimes for conditionally unstable flow over an idealized three-dimensional mesoscale mountain, Preprint, Ninth Conference on Mesoscale Processes, Amer. Meteor. Soc., Fort Lauderdale, FL, 405-408, 2001.

Chen, S.-H. and Lin, Y. L.: Effects of moist froude number and CAPE on a conditionally unstable flow over a mesoscale mountain ridge, J. Atmos. Sci., 62, 331-350, 2005.

Chiao, S., Lin, Y. L., and Kaplan, M.: Numerical study of the orographic forcing of heavy precipitation during MAP IOP-2B, Mon. Weather Rev., 132, 2184-2203, 2004.

Chu, C. M. and Lin, Y. L.: Effects of orography on the generation and propagation of mesoscale convective systems in a twodimensional conditionally unstable flow, J. Atmos. Sci., 57, 3817-3837, 2000.

Colle, B. A.: Sensitivity of orographic precipitation to changing ambient conditions and terrain geometries: an idealized modelling perspective, J. Atmos. Sci., 61, 588-606, 2004.

Dasari, H. P. and Salgado, R.: Numerical modelling of heavy precipitation event over Madeira Island in Portugal: sensitivity to different micro physical process, Meteorol. Appl., 22, 113-127, 2015.

del Carmen Llasat, M. and Siccardi, F.: A reflection about the social and technological aspects in flood risk management - the case of the Italian Civil Protection, Nat. Hazards Earth Syst. Sci., 10, 109-119, https://doi.org/10.5194/nhess-10-109-2010, 2010.

Durran, D. R. and Klemp, J. B.: On the effects of moisture on the Brunt-Väisälä frequency, J. Atmos. Sci., 39, 3846-3879, 1982.

Federico, S., Avolio, E., Pasqualoni, L., and Bellecci, C.: Atmospheric patterns for heavy rain events in Calabria, Nat. Hazards Earth Syst. Sci., 8, 1173-1186, https://doi.org/10.5194/nhess-81173-2008, 2008.

Fernandez-Montes, S., Seubert, S., Rodrigo, F. S., RasillaÁlvarez, D. F., Hertig, E., Esteban, P., and Philipp, A.: Circulation types and extreme precipitation days in the Iberian Penin- sula in the transition seasons: spatial links and temporal changes, Atmos. Res., 138, 41-58, 2014.

Foresti, L. and Pozdnoukhov, A.: Exploration of alpine orographic precipitation patterns with radar image processing and clustering techniques, Meteorol. Appl., 19, 407-419, 2012.

Funk, T. W.: Forecasting techniques utilized by the Forecasting Brach of the National Meteorological Centre during a major convective precipitation event, Weather Forecast., 6, 548-564, 1991.

Garavaglia, C. R., Doyle, M. E., and Barros, V. R.: Statistical relationship between atmospheric circulation and extreme precipitation in La Plata Basin, Meteorol. Appl., 21, 553-562, 2014.

Gonzalez, S. and Bech, J.: Extreme point rainfall temporal scaling: a long term (1805-2014) regional and seasonal analysis in Spain, Int. J. Climatol., 37, 5068-5079, https://doi.org/10.1002/joc.5144, 2017.

Grumm, R. H., Junker, N. W., Hart, R., and Bosart, L. F.: Can possible heavy precipitation events be identified by comparing various parameters to the climatological norms?, Preprints, 19th Conference on Weather Analysis and Forecasting, Amer. Meteor. Soc., San Antonio, TX, 160-163, 2002.

Hickey, K.: The Impact of Hurricanes on the Weather of Western Europe, Recent Hurricane Research - Climate, Dynamics, and Societal Impacts, edited by: Lupo, A., ISBN-13: 978-953-307238-8, InTech, available at: http://www.intechopen.com/books/ recent-hurricane-research-climate-dynamics-andsocietal-impacts/ the-impact-of-hurricanes-on-the-weather-of-western-europe, 77-84, 2011.

Jansà, A., Genovés, A., Picornell, M. A., Campins. J., Riosalido, R., and Carretero, O.: Western Mediterranean cyclones and heavy rain, Part II: Statistical approach, Meteorol. Appl., 8, 43-56, 2001.

Lang, J. L. and Barros, A. P.: Winter storms in the central Himalayas, J. Meteorol. Soc. Jpn., 82, 829-844, 2004.

Lin, Y. L., Chiao, S., Wang, T., Kaplan, M. L., and Waglarz, R. P.: Some common ingredients for heavy orographic precipitation, Weather Forecast., 16, 633-659, 2001.

Ma, K. and Bosart, L. F.: A synoptic overview of a heavy rain event in southern China, Weather Forecast., 5, 89-112, 1990.

Martín-Vide, J.: Aplicación de la clasificación sinóptica automática de Jenkinson y Collison a días de precipitación torrencial en el este de España, in: La información climática como herramienta de gestión ambiental, edited by: Cuadrat, J. M., Vicente, S. M., and Saz, M. A., Zaragoza, Universidad de Zaragoza, 123-127, 2002.

Massari, C., Brocca, L., Moramarco, T., Tramblay, Y., and DidonLescot, J. F.: Potential of soil moisture observations in flood modelling: estimating initial conditions and correcting rainfall, Adv. Water Resour., 74, 44-53, 2014.

Merino, A., Fernández-Vaquero, M., López, L., FernándezGonzález, S., Hermida, L., Sánchez, J. L., García-Ortega, E., and Gascón, E.: Large-scale patterns of daily precipitation extremes on the Iberian Peninsula, Int. J. Climatol., 36, 3873-3891, https://doi.org/10.1002/joc.4601, 2016.

Miglietta, M. M. and Rotunno, R.: Numerical simulations of conditional unstable flows over a mountain ridge, J. Atmos. Sci., 66, 1865-1885, 2009.

Prat, O. P. and Barros, A. P.: Ground observations to characterize the spatial gradients and vertical structure of orographic 
precipitation-Experiments in the inner region of the Great Smoky Mountains, J. Hydrol., 391, 141-156, 2010.

Ramis, C., Romero, R., Homar, V., and Alonso, S.: The role of mathematics in the understanding of the dynamics of meteorogical Situations that produce heavy rain over the Spanish Mediterranean zone, Monografías de la Real Academia de Ciencias de Zaragoza, 31, 175-198, 2009.

Reale, M. and Lionello, P.: Synoptic climatology of winter intense precipitation events along the Mediterranean coasts, Nat. Hazards Earth Syst. Sci., 13, 1707-1722, https://doi.org/10.5194/nhess-13-1707-2013, 2013.

Riesco, J., Mora, M., de Pablo, F., and Soriano, L.: Severe precipitation events over the western Mediterranean Sea: a case study, Atmos. Res., 127, 47-63, https://doi.org/10.1016/j.atmosres.2013.03.001, 2013.

Rigo, T. and Llasat, M. C.: A methodology for the classification of convective structures using meteorological radar: Application to heavy rainfall events on the Mediterranean coast of the Iberian Peninsula, Nat. Hazards Earth Syst. Sci., 4, 59-68, https://doi.org/10.5194/nhess-4-59-2004, 2004.

Romero, R., Ramis, C., and Guijarro, J. A.: Daily precipitation patterns in the Spanish Mediterranean area: an objective classification, Int. J. Climatol., 19, 95-112, 1999.

Schumacher, R. S. and Johnson, R. H.: Characteristics of US extreme rain events during 1999-2003, Weather Forecast., 21, 6985, 2006.

Schwartz, B. E., Chappell, C. F., Togstad, W. E., and Zong, X. P.: The Minneapolis flash flood: meteorological analysis and operational response, Weather Forecast., 5, 3-21, 1990
Stefanescu, V., Stefan, S., and Georgescu, F.: Spatial distribution of heavy precipitation events in Romania between 1980 and 2009, Meteorol. Appl., 21, 684-694, 2014.

Teixeira, M. S. and Prakki, S.: Dynamical and synoptic characteristics of heavy precipitation episodes in southern Brazil, Mon. Weather Rev, 135, 598-617, 2007.

Uppala, S. M., Kållberg, P. W., Simmons, A. J., Andrae, U., da Costa Bechtold, V., Fiorino, M., Gibson, J. K., Haseler, J., Hernandez, A., Kelly, G. A., Li, X., Onogi, K., Saarinen, S., Sokka, N., Allan, R. P., Andersson, E., Arpe, K., Balmaseda, M. A., Beljaars, A. C. M., van de Berg, L., Bidlot, J., Bormann, N., Caires, S., Chevallier, F., Dethof, A., Dragosavac, M., Fisher, M., Fuentes, M., Hagemann, S., Holm, E., Hoskins, B. J., Isaksen, L., Janssen, P. A. E. M., Jenne, R., McNally, A. P., Mahfouf, J- F., Morcrette, JJ., Rayner, N. A., Saunders, R. W., Simon, P., Sterl, A., Trenberth, K. E., Untch, A., Vasiljevic, D., Viterbo, P., and Woollen, J.: The ERA-40 reanalysis, Q. J. Roy. Meteor. Soc., 131, 2961-3012, 2005.

Yu, C. K. and Cheng, L. W.: Radar observations of intense orographic precipitation associated with typhoon Xangsane (2000), Mon. Weather Rev., 136, 497-521, 2008.

Yu, W., Nakakita, E., Kim, S., and Yamaguchi, K.: Mechanisms for convection development in a long-lasting heavy precipitation event over southeastern Italy, J. Hydrol., 531, 494-507, 2015. 